\title{
Merkel Cell Carcinoma pM1c TNM Finding v7
}

National Cancer Institute

\section{Source}

National Cancer Institute. Merkel Cell Carcinoma pM1c TNM Finding v7. NCI Thesaurus.

Code C88536.

Merkel cell carcinoma with metastasis to all other visceral sites. (from AJCC 7th Ed.) 